\title{
Synthesis and biological activity of $\boldsymbol{N}$-substituted- tetrahydro-y-carbolines containing peptide residues
}

\author{
Nadezhda V. Sokolova ${ }^{1,2}$, Valentine G. Nenajdenko*1,3,§, \\ Vladimir B. Sokolov' ${ }^{2}$, Daria V. Vinogradova ${ }^{2}$, Elena F. Shevtsova ${ }^{2}$, \\ Ludmila G. Dubova ${ }^{2}$ and Sergey O. Bachurin ${ }^{* 2}$
}

\section{Full Research Paper}

\section{Address:}

${ }^{1}$ Department of Chemistry, Moscow State University, Leninskie Gory

1, Moscow, 119992, Russia, ${ }^{2}$ Institute of Physiologically Active

Compounds, Russian Academy of Sciences, Severny proezd 1, Chernogolovka, 142432, Russia and ${ }^{3} \mathrm{~A}$. N. Nesmeyanov Institute of Organoelement Compounds, Russian Academy of Sciences, Vavilov str. 28, 119991 Moscow, Russian Federation

\section{Email:}

Valentine G. Nenajdenko* - nen@acylium.chem.msu.ru;

Sergey O. Bachurin ${ }^{*}$ - bachurin@ipac.ac.ru

* Corresponding author

§ Phone: +7 495 9392276; Fax: +7 4959328846

Keywords:

mitochondrial membrane potential; mitochondrial permeability transition; multicomponent; peptides; tetrahydro-y-carbolines; Ugi multicomponent reaction
Open Access

Beilstein J. Org. Chem. 2014, 10, 155-162.

doi:10.3762/bjoc.10.13

Received: 14 October 2013

Accepted: 06 December 2013

Published: 15 January 2014

This article is part of the Thematic Series "Multicomponent reactions II".

Guest Editor: T. J. J. Müller

(C) 2014 Sokolova et al; licensee Beilstein-Institut. License and terms: see end of document.

\begin{abstract}
The synthesis of novel peptide conjugates of $N$-substituted-tetrahydro- $\gamma$-carbolines has been performed using the sequence of the Ugi multicomponent reaction and $\mathrm{Cu}(\mathrm{I})$-catalyzed click chemistry. The effect of obtained $\gamma$-carboline-peptide conjugates on the rat liver mitochondria was evaluated. It was found that all compounds in the concentration of $30 \mu \mathrm{M}$ did onot induce depolarization of mitochondria but possessed some inhibitory effect on the mitochondria permeability transition. The original $N$-substitutedtetrahydro- $\gamma$-carbolines containing an terminal alkyne group demonstrated a high prooxidant activity, whereas their conjugates with peptide fragments slightly inhibited both autooxidation and the $t$-BHP-induced lipid peroxidation.
\end{abstract}

\section{Introduction}

The design and synthesis of new efficient pharmaceutical drugs for the treatment and prevention of a wide range of neurodegenerative diseases, such as Alzheimer's dementia, Parkinsonism and the amyotrophic lateral sclerosis, is of considerable interest in modern medicinal chemistry. Mitochondrial dysfunction was found to play a crucial role in the pathogenesis of these diseases [1-3]. Thus, one of the specific symptoms of such pathologies is a decrease in the ability of mitochondria to regulate the calcium homeostasis in cells and malfunction of mitochondrial permeability transition (MPT) that represents a key step in the 
cascades of cell death. From this point of view, mitochondria and the MPT process are very attractive targets for the search of new neuroprotective agents [4,5].

Several promising mitochondria-targeting neuroprotectors have been reported in the literature. Thus, the antihistaminic drug dimebon $[6,7]$, which relates to tetrahydro- $\gamma$-carboline derivatives, has been found to stabilize and improve mitochondrial functions in different in vivo and in vitro models $[8,9]$ (Figure 1). Another promising class of neuroprotectors are cellpermeable mitochondria-targeting synthetic small peptides, for example, the SS (Szeto-Schiller) peptide antioxidants [10] (Figure 1). These peptides were found to scavenge hydrogen peroxide and peroxynitrite and inhibit lipid peroxidation in vitro. By reducing mitochondrial reactive oxygen species, they inhibit MPT and cytochrome c release, thus protecting cells from oxidative cell death [11].

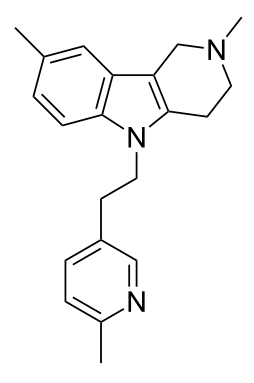

dimebon

\section{H-Dmt-D-Arg-Phe-Lys- $\mathrm{NH}_{2}$ \\ SS-02}

H-D-Arg-Dmt-Lys-Phe-NH $\mathrm{NH}_{2}$

SS-31

Dmt $=$ 2',6'-dimethyltyrosine
Figure 1: Structures of dimebon and SS peptides.
We expected that the conjugation of tetrahydro- $\gamma$-carbolines with synthetic peptides could lead to a new class of promising neuroprotectors affecting brain mitochondria. Thus, we synthesized $\mathrm{N}$-substituted tetrahydro- $\gamma$-carbolines and their peptide conjugates and investigated the action of the obtained compounds on the mitochondria membrane potential, mitochondrial permeability transition and lipid peroxidation.

\section{Results and Discussion}

The starting N-substituted tetrahydro- $\gamma$-carbolines 3a-d containing a terminal alkyne group were prepared in good yields by heating compounds $\mathbf{1 a - d}[12,13]$ with propargyl acrylate (2) in the presence of catalytic amounts of CsF (Scheme 1).

The corresponding protected azidopeptides 5 [14,15] are accessible by the Ugi multicomponent reaction [16-19] of chiral isocyanoazides 4 [20] with carbonyl compounds, amines and Boc-protected amino acids (Scheme 2). As we showed before, the racemization of the chiral centre of the isocyanoazide does not occur under the conditions of the Ugi reaction [20]. This approach permits to prepare a broad variety of azidopeptides using multicomponent methodology.

The modification of $\mathrm{N}$-substituted tetrahydro- $\gamma$-carbolines 3a-d by peptide fragments was performed using $\mathrm{Cu}(\mathrm{I})$-catalyzed click chemistry - one of the most effective conjugation methods $[21,22]$. Thus, heating the educts with $\mathrm{Cu}(\mathrm{II}) /$ sodium ascorbate in a biphasic mixture of $\mathrm{CH}_{2} \mathrm{Cl}_{2} / \mathrm{H}_{2} \mathrm{O}$ during $1 \mathrm{~h}$ provided compounds $6 \mathbf{a}-\mathbf{g}$ (Scheme 3 ). According to the ${ }^{13} \mathrm{C}$ NMR spectra, the click reaction proceeds regioselective in all cases affording the desired conjugates $\mathbf{6} \mathbf{a}-\mathbf{g}$ in good yields.

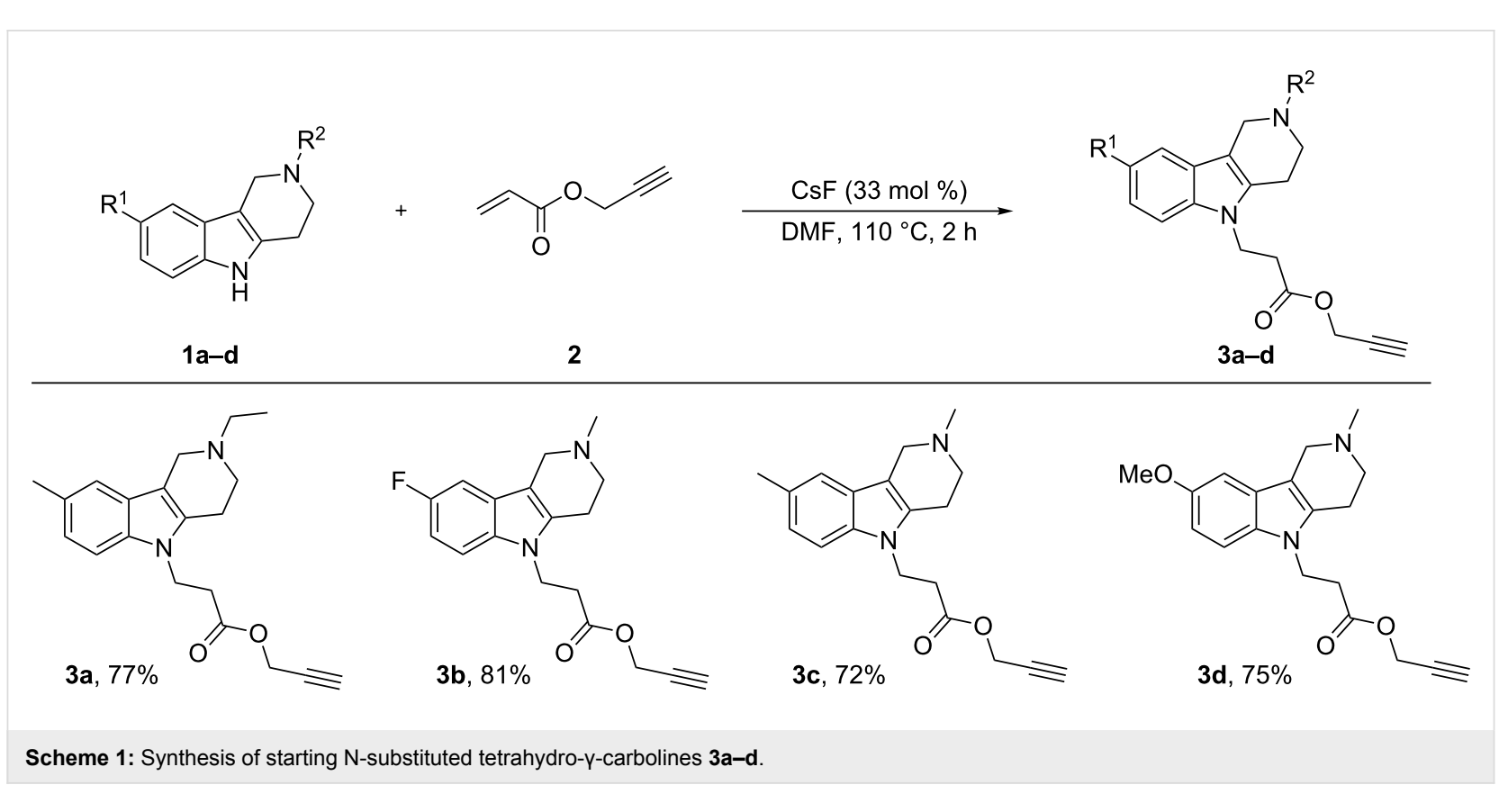


<smiles>[R]C(N)CN</smiles><smiles></smiles><smiles>[R7]C(N)C(=O)O</smiles>

$\mathrm{MeOH}, \mathrm{rt}, 24 \mathrm{~h}$<smiles>[R3]C(C[NH3+])NC(=O)C([R])([R])N([R])C(=O)C([R3])NC(=O)O</smiles><smiles>CCC(C)C(NC(=O)OCc1ccccc1)C(=O)N(CC)C(C)(C)C(=O)NC(C)C[18O]</smiles>

$5 a$<smiles>CC(C)NC(=O)C(C)N(C(=O)O)C(C)(C)C(=O)NCCN</smiles><smiles>CC(C)C(C[18OH])NC(=O)CN(C(=O)[18OH])C(=O)C(CO)NC(=O)OC(C)(C)C</smiles>

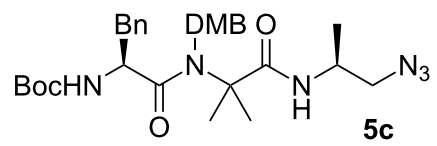

$5 c$

Scheme 2: Synthesis of peptides 5 through the Ugi reaction.

Next, we turned our attention to the deprotection of the amine function in the peptide residues, in order to obtain water-soluble conjugates. Thus, $N$-Boc protecting groups were removed from compounds $\mathbf{6 a - g}$ with $2 \mathrm{M} \mathrm{HCl}$ in methanol to give the corresponding dihydrochloride salts $\mathbf{7 a - g}$ in nearly quantitative yields (Scheme 4).

The final dihydrochloride salts $\mathbf{7} \mathbf{a}-\mathbf{g}$ were tested on rat liver mitochondria (RLM) using standards tests: lipid peroxidation (LP), mitochondrial membrane potential $\left(\Delta \Psi_{\mathrm{m}}\right)$ and $\mathrm{Ca}^{2+}$. induced mitochondrial permeability transition (MPT).

On the day of the experiment, adult male Wistar rats fasted overnight were euthanized in a $\mathrm{CO}_{2}$ chamber followed by decapitation. The procedure is in compliance with the Guidelines for Animal Experiments at IPAC RAS. Rat liver mitochondria were isolated by conventional differential centrifugation as previously described [23]. All experiments were provided with mitochondria energized by succinate in the presence of rotenone.

The influence of compounds on spontaneous or induced by tertbutylhydroperoxide ( $t$-BHP) LP was studied by the standard assay [24]. The extent of LP was measured spectrophotometrically $\left(\lambda_{\max }=532 \mathrm{~nm}\right)$ and malondialdehyde-thiobarbituric acid adduct concentrations (MDA, expressed in $\mathrm{nmol} / \mathrm{mg}$ protein) were obtained by interpolation with a MDA standard curve from commercially available 1,1,3,3-tetramethoxypropane. All experiments were repeated using three different preparations of isolated rat liver mitochondria.

Mitochondrial membrane potential was monitored using safranine $\mathrm{O}$ [23]. The ability of the compounds to affect MPT was assessed by monitoring mitochondria swelling caused by calcium chloride addition in a plate reader (Victor3, Perkin Elmer). Swelling rate $\left(V_{\max }\right)$ was calculated as a slope of the steepest portion of the plot of swelling (light scattering) versus time $\left(\mathrm{dA}_{530} \times 1000 \times \mathrm{min}^{-1}\right)$.

$\mathrm{N}$-substituted tetrahydro- $\gamma$-carbolines $\mathbf{3 a}-\mathbf{d}$ possessed a prooxidant activity. These compounds potentiated the $t$-BHPinduced LP and also induced LP of liver mitochondria. Their peptide conjugates not only lost pro-oxidant activity but, moreover, some of these compounds could inhibit both mitochondrial lipid auto-oxidation and the $t$-BHP-induced LP (Table 1).

At the concentration of $100 \mu \mathrm{M}(200 \mathrm{nmol} / \mathrm{mg}$ mitochondria) the studied compounds caused a week decrease of $\Delta \Psi_{\mathrm{m}}$ and demonstrated no significant influence on mitochondrial swelling (data not shown). But at higher pharmacologically relevant concentration of $30 \mu \mathrm{M}(60 \mathrm{nmol} / \mathrm{mg}$ mitochondria) all compounds did not affect the $\Delta \Psi_{\mathrm{m}}$ and increased the resistance of mitochondria to calcium-induced MPT (Table 2). The results of biological evaluation revealed an antioxidant and mitoprotective potential of the new synthesized peptide-modified N-substi- 

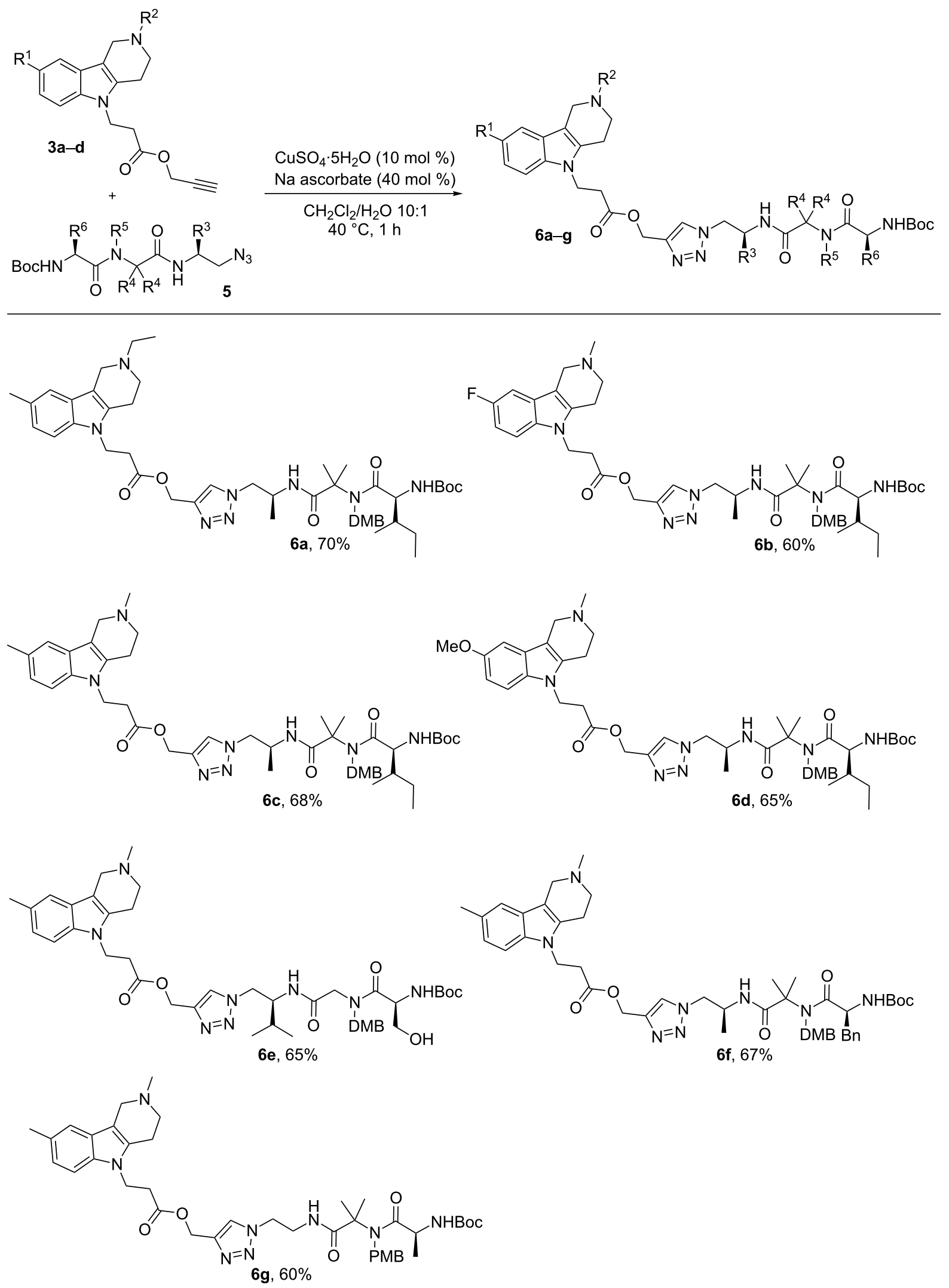

Scheme 3: Synthesis of $\mathrm{N}$-substituted tetrahydro-y-carbolines containing protected peptide residues. 


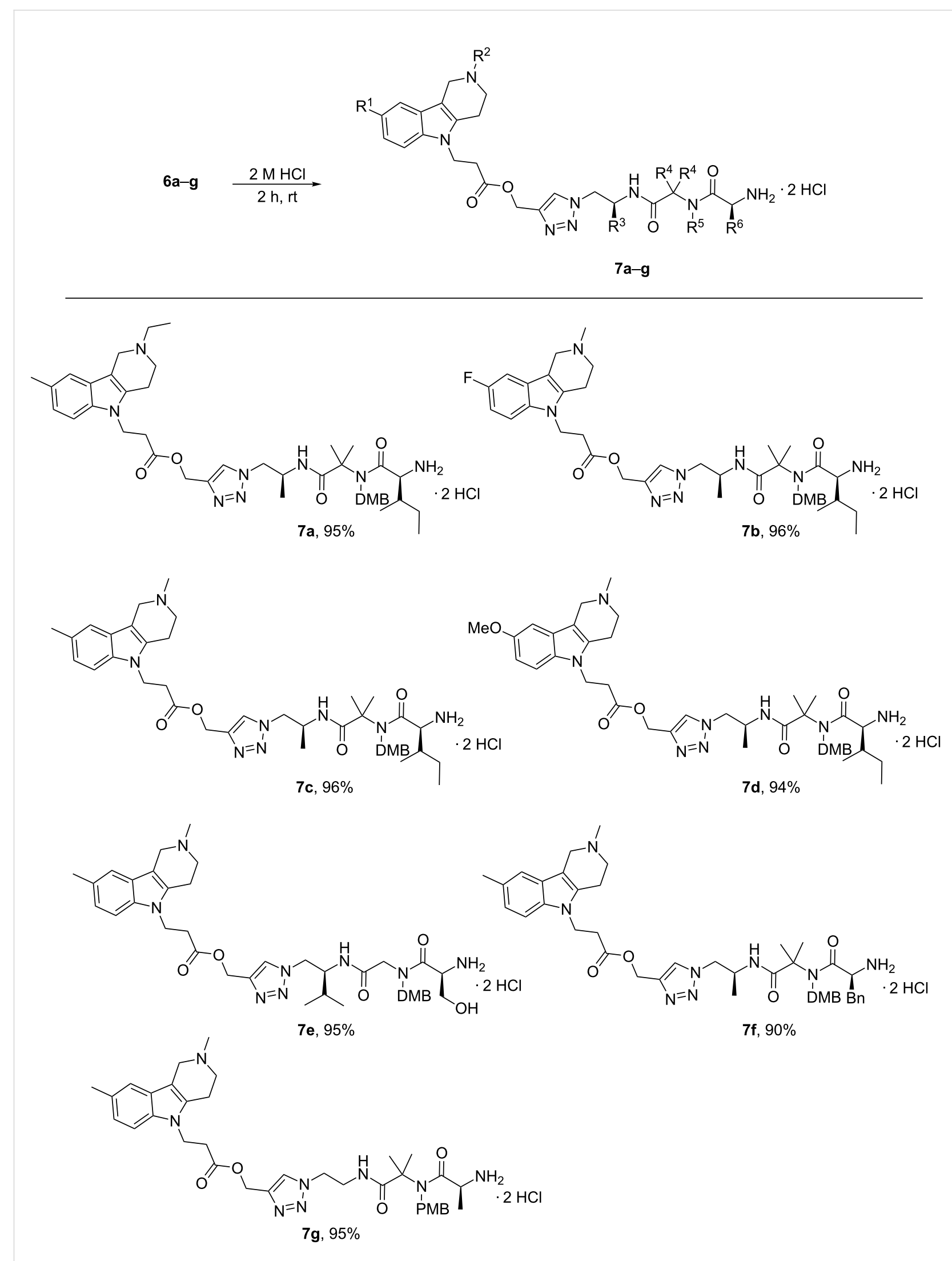

Scheme 4: Synthesis of dihydrochloride salts $7 \mathbf{a}-\mathbf{g}$. 
Table 1: The influence of N-substituted tetrahydro- $Y$-carbolines and their peptide conjugates on LP of rat liver mitochondria.

\begin{tabular}{ccc} 
Compound & $\begin{array}{c}\text { LP in the presence of } 0.1 \mathrm{mM} \text { compound, } \\
\text { nmol MDA/mg protein }\end{array}$ & $\begin{array}{c}\text { Influence of } 0.1 \mathrm{mM} \text { compound on } 1.6 \mathrm{mM} t \text {-BHP-induced LP, } \\
\text { nmol MDA/mg protein }\end{array}$ \\
\hline no compounds & $0.48 \pm 0.01$ & $0.91 \pm 0.02$ \\
3a & $1.72 \pm 0.05$ & $7.63 \pm 0.05$ \\
3b & $1.96 \pm 0.04$ & $6.09 \pm 0.08$ \\
3c & $1.72 \pm 0.08$ & $6.05 \pm 0.16$ \\
$\mathbf{3 d}$ & $1.81 \pm 0.08$ & $7.64 \pm 0.09$ \\
$\mathbf{7 a}$ & $0.39 \pm 0.02$ & $0.86 \pm 0.04$ \\
$\mathbf{7 b}$ & $0.41 \pm 0.02$ & $0.87 \pm 0.06$ \\
$\mathbf{7 c}$ & $0.39 \pm 0.02$ & $0.79 \pm 0.01$ \\
$\mathbf{7 d}$ & $0.38 \pm 0.02$ & $0.81 \pm 0.02$ \\
$\mathbf{7 e}$ & $0.4 \pm 0.03$ & $0.92 \pm 0.04$ \\
$\mathbf{7 f}$ & $0.37 \pm 0.01$ & $0.75 \pm 0.02$ \\
$\mathbf{7 g}$ & $0.62 \pm 0.02$ & $0.95 \pm 0.05$ \\
& & \\
\hline
\end{tabular}

tuted tetrahydro- $\gamma$-carbolines. Further investigations of this class of compounds may allow finding a promising approach to cytoprotection, in particularly, neuroprotection.

Table 2: The influence of the peptide conjugates of $\mathrm{N}$-substituted tetrahydro- $y$-carbolines on rat liver mitochondria swelling. ${ }^{a}$

\begin{tabular}{cc} 
Compounds & $\Delta \mathrm{A} 530 / \mathrm{min}(\%$ of control) \\
\hline $\mathbf{7 a}$ & $70.5 \pm 4.6$ \\
$\mathbf{7 b}$ & $79.9 \pm 8.1$ \\
$\mathbf{7 c}$ & $80.9 \pm 8.0$ \\
$\mathbf{7 d}$ & $76.2 \pm 7.5$ \\
$\mathbf{7 e}$ & $72.4 \pm 2.7$ \\
$\mathbf{7 f}$ & $70.2 \pm 8.6$ \\
$\mathbf{7 g}$ & $79.0 \pm 6.7$ \\
\hline
\end{tabular}

${ }^{a}$ Quantification of swelling was measured as the maximal velocity of A530 change after $\mathrm{CaCl}_{2}$ addition. The values were normalized against the control values, set to $100 \%$. Data are expressed as means $\pm \mathrm{SD}(n=3$ or 4$)$.

\section{Conclusion}

In summary, we described the conjugation of $\mathrm{N}$-substituted tetrahydro- $\gamma$-carbolines containing a terminal alkyne group 3a-d with various azidopeptides $\mathbf{5}$ (prepared by Ugi multicomponent reaction) through the $\mathrm{Cu}(\mathrm{I})$-catalyzed Huisgen 1,3dipolar cycloaddition. The activity of the obtained compounds on rat liver mitochondria functional characteristics, such as mitochondrial transmembrane potential, calcium-induced mitochondrial permeability transition and lipid peroxidation of mitochondrial membrane was evaluated. It was found that all compounds at a concentration of $30 \mu \mathrm{M}$ did not induce depolarization of mitochondria but possessed some inhibitory effect on the mitochondria permeability transition. The starting N-substituted tetrahydro- $\gamma$-carbolines $\mathbf{3 a - d}$ demonstrated a high pro- oxidant activity, whereas their peptide conjugates inhibited both auto-oxidation and the $t$-BHP-induced lipid peroxidation.

\section{Experimental General Information}

${ }^{1} \mathrm{H}$ and ${ }^{13} \mathrm{C}$ NMR spectra were recorded in deuterated solvents on a Bruker Avance $400 \mathrm{MHz}$ spectrometer. ${ }^{19} \mathrm{~F}$ NMR spectra were recorded on a Bruker DXP $200 \mathrm{MHz}$ spectrometer. ${ }^{1} \mathrm{H}$ and ${ }^{13} \mathrm{C}$ chemical shifts are reported in parts per million (ppm) or $\delta$ values downfield from TMS as internal standard. Deuterated solvent peaks were used as internal references: $\mathrm{CDCl}_{3}$ at 7.25 and $77.00 \mathrm{ppm} .{ }^{19} \mathrm{~F}$ chemical shifts are reported on $\delta$ scale (in ppm) downfield from $\mathrm{CF}_{3} \mathrm{COOH}$. Liquid chromatography was performed using Fluka silica gel $60(0.063-0.200 \mathrm{~mm})$. Melting points were determined with an Electrothermal IA9100 Digital Melting Point Apparatus and are uncorrected. Optical rotations were measured on a Perkin-Elmer 341 polarimeter at $589 \mathrm{~nm}$. High-resolution mass spectra (HRMS) were measured on a MicrOTOF II (Bruker Daltonics) spectrometer.

Compounds 1a-d were obtained from the respective arylhydrazine hydrochlorides and $\mathrm{N}$-substituted 4-piperidones using Fischer indole synthesis [12,13]. Propargyl acrylate (2) was obtained from propargyl alcohol and acryloyl chloride according to procedure described in [25].

\section{General procedure for the synthesis of compounds 3a-d: A} mixture of correspondingly substituted 2,3,4,5-tetrahydro- $1 H$ pyrido[4,3-b]indole 1a-d ( $2 \mathrm{mmol}), 0.22 \mathrm{~g}(2 \mathrm{mmol})$ acrylic acid propyn-2-yl ester (2) and $0.1 \mathrm{~g}(0.66 \mathrm{mmol})$ of $\mathrm{CsF}$ in $1 \mathrm{~mL}$ of DMF was stirred at $110^{\circ} \mathrm{C}$ during $2 \mathrm{~h}$. The solvent was removed in vacuo $(\sim 3 \mathrm{mmHg})$ and the product was extracted from the residue with $\mathrm{CH}_{2} \mathrm{Cl}_{2}$. The solvent was removed in 
vacuo and the residue was purified by column chromatography $\left(\mathrm{MeOH} / \mathrm{CHCl}_{3}\right.$ 1:5).

General procedure for the Ugi-4CC synthesis of peptides 5: As described in [14], the corresponding amine $(1 \mathrm{mmol})$ and acetone or $\mathrm{CH}_{2} \mathrm{O}\left(40 \%\right.$ in $\left.\mathrm{H}_{2} \mathrm{O}, 1 \mathrm{mmol}\right)$ were dissolved in $5 \mathrm{~mL}$ of $\mathrm{MeOH}$ and $N$-Boc-protected amino acid $(1 \mathrm{mmol})$ and isocyanide $4(1 \mathrm{mmol})$ were added at room temperature. The mixture was stirred for $24 \mathrm{~h}$. The solvent was removed in vacuo and the residue was purified by column chromatography (hexanes/ethyl acetate) to give compounds 5 .

General procedure for the synthesis of compounds $6 \mathrm{a}-\mathrm{g}$ : To a solution of acetylene $3(0.5 \mathrm{mmol})$ in $5 \mathrm{~mL}$ of $\mathrm{CH}_{2} \mathrm{Cl}_{2}$ was added the peptide $5(0.5 \mathrm{mmol}), 0.012 \mathrm{~g}(0.05 \mathrm{mmol})$ of $\mathrm{CuSO}_{4} \cdot 5 \mathrm{H}_{2} \mathrm{O}$ in $0.25 \mathrm{~mL}$ of $\mathrm{H}_{2} \mathrm{O}$ and $0.04 \mathrm{~g}(0.2 \mathrm{mmol})$ of sodium ascorbate in $0.25 \mathrm{~mL}$ of $\mathrm{H}_{2} \mathrm{O}$. The reaction mixture was stirred at $40^{\circ} \mathrm{C}$ for $1 \mathrm{~h}$. After the reaction was completed $10 \mathrm{~mL}$ of $\mathrm{CH}_{2} \mathrm{Cl}_{2}$ was added and the reaction mixture was washed with aq $\mathrm{NH}_{3}$ and then with water. The organic layer was separated and dried over $\mathrm{Na}_{2} \mathrm{SO}_{4}$. The solvent was removed in vacuo and the residue was purified by column chromatography $\left(\mathrm{CH}_{2} \mathrm{Cl}_{2} /\right.$ $\mathrm{MeOH}$ 10:1).

General procedure for the synthesis of dihydrochlorides 7a-g: The corresponding compound $\mathbf{6 a}-\mathbf{g}(0.12 \mathrm{mmol})$ was dissolved in $1 \mathrm{~mL}(2 \mathrm{mmol})$ of a $2 \mathrm{M}$ solution of $\mathrm{HCl}$ in $\mathrm{MeOH}$. The reaction mixture was stirred at room temperature for $2 \mathrm{~h}$. The solvent was removed in vacuo and the residue was dissolved in $5 \mathrm{~mL}$ of EtOH. Then the solvent was evaporated and $5 \mathrm{~mL}$ of acetonitrile were added to the residue. After evaporation of the solvent the corresponding dihydrochlorides $\mathbf{7 a}-\mathbf{g}$ were obtained.

\section{Supporting Information}

\section{Supporting Information File 1}

General information and characterization data for all compounds.

[http://www.beilstein-journals.org/bjoc/content/ supplementary/1860-5397-10-13-S1.pdf]

\section{Acknowledgements}

This work was supported by the Russian Foundation for Basic Research (Grants No. 12-03-31582 and 12-03-00292).

\section{References}

1. Bachurin, S. O.; Shevtsova, E. P.; Lermontova, N. N.; Serkova, T. P.; Ramsay, R. R. NeuroToxicology 1996, 17, 897-904.
2. Knott, A. B.; Perkins, G.; Schwarzenbacher, R.; Bossy-Wetzel, E. Nat. Rev. Neurosci. 2008, 9, 505-518. doi:10.1038/nrn2417

3. Lee, J.; Boo, J. H.; Ryu, H. Adv. Drug Delivery Rev. 2009, 61, 1316-1323. doi:10.1016/j.addr.2009.07.016

4. Bachurin, S. O. Vopr. Med. Khim. 2001, 47, 155-197.

5. Eckert, G. P.; Renner, K.; Eckert, S. H.; Eckmann, J.; Hagl, S.; Abdel-Kader, R. M.; Kurz, C.; Leuner, K.; Muller, W. E. Mol. Neurobiol. 2012, 46, 136-150. doi:10.1007/s12035-012-8271-z

6. Doody, R. S.; Gavrilova, S. I.; Sano, M.; Thomas, R. G.; Aisen, P. S.; Bachurin, S. O.; Seely, L.; Hung, D. Lancet 2008, 372, 207-215. doi:10.1016/S0140-6736(08)61074-0

7. Steele, J. W.; Gandy, S. Autophagy 2013, 9, 617-618. doi:10.4161/auto.23487

8. Zhang, S.; Hedskog, L.; Hansson-Petersen, C. A.; Winblad, B.; Ankarcrona, M. J. Alzheimer's Dis. 2010, 21, 389-402. doi:10.3233/JAD-2010-100174

9. Eckert, S. H.; Eckmann, J.; Renner, K.; Eckert, G. P.; Leuner, K.; Muller, W. E. J. Alzheimer's Dis. 2012, 31, 21-32. doi:10.3233/JAD-2012-120310

10. Zhao, K.; Zhao, G.-M.; Wu, D.; Soong, Y.; Birk, A. V.; Schiller, P. W.; Szeto, H. H. J. Biol. Chem. 2004, 279, 34682-34690. doi:10.1074/jbc.M402999200

11. Szeto, H. H. AAPS J. 2006, 8, E277-E283.

12. Kalin, J. H.; Butler, K. V.; Akimova, T.; Hancock, W. W.; Kozikowski, A. P. J. Med. Chem. 2012, 55, 639-651. doi:10.1021/jm200773h

13. Hung, D. T.; Protter, A. A.; Jain, R. P.; Chakravarty, S.; Giorgetti, M. Pyrido[4,3-b]indoles Containing Rigid Moieties. U.S. Patent 20100216814, Aug 26, 2010.

14. Sokolova, N. V.; Latyshev, G. V.; Lukashev, N. V.; Nenajdenko, V. G. Org. Biomol. Chem. 2011, 9, 4921-4926. doi:10.1039/c0ob01188f

15. Vorobyeva, D. V.; Sokolova, N. V.; Nenajdenko, V. G.; Peregudov, A. S.; Osipov, S. N. Tetrahedron 2012, 68, 872-877. doi:10.1016/j.tet.2011.11.037

16. Dömling, A.; Ugi, I. Angew. Chem., Int. Ed. 2000, 39, 3168-3210. doi:10.1002/1521-3773(20000915)39:18<3168::AID-ANIE3168>3.0.CO $; 2-U$

17. Dömling, A. Chem. Rev. 2006, 106, 17-89. doi:10.1021/cr0505728

18. Gulevich, A. V.; Zhdanko, A. G.; Orru, R. V. A.; Nenajdenko, V. G. Chem. Rev. 2010, 110, 5235-5331. doi:10.1021/cr900411f

19. Nenajdenko, V. G., Ed. Isocyanide Chemistry: Application in Synthesis and Materials Science; Wiley-VCH: Weinheim, Germany, 2012. doi:10.1002/9783527652532

20. Nenajdenko, V. G.; Gulevich, A. V.; Sokolova, N. V.; Mironov, A. V.; Balenkova, E. S. Eur. J. Org. Chem. 2010, 1445-1449. doi:10.1002/ejoc.200901326

21. Tornøe, C. W.; Cristensen, C.; Meldal, M. J. Org. Chem. 2002, 67, 3057-3064. doi:10.1021/jo011148j

22. Rostovtsev, V. V.; Green, L. G.; Fokin, V. V.; Sharpless, K. B. Angew. Chem., Int. Ed. 2002, 114, 2708-2711. doi:10.1002/1521-3757(20020715)114:14<2708::AID-ANGE2708>3.0. CO;2-0

23. Bachurin, S. O.; Shevtsova, E. P.; Kireeva, E. G.; Oxenkrug, G. F.; Sablin, S. O. Ann. N. Y. Acad. Sci. 2003, 993, 334-344. doi:10.1111/j.1749-6632.2003.tb07541.x

24. Ohkawa, H.; Ohishi, N.; Yagi, K. Anal. Biochem. 1979, 95, 351-358. doi:10.1016/0003-2697(79)90738-3

25. Harvey, D. F.; Lund, K. P.; Neil, D. A. J. Am. Chem. Soc. 1992, 114, 8424-8434. doi:10.1021/ja00048a012 


\section{License and Terms}

This is an Open Access article under the terms of the Creative Commons Attribution License

(http://creativecommons.org/licenses/by/2.0), which permits unrestricted use, distribution, and reproduction in any medium, provided the original work is properly cited.

The license is subject to the Beilstein Journal of Organic Chemistry terms and conditions:

(http://www.beilstein-journals.org/bjoc)

The definitive version of this article is the electronic one which can be found at:

doi:10.3762/bjoc. 10.13 